Research Article

\title{
The Degree of Cystocele and Rectocele with Hiatal Area Levator Ani
}

\section{Derajat Cystocele dan Rectocele dengan Hiatal Area Levator Ani}

\author{
Fernandi Moegni, Hari Santoso \\ Department of Obstetrics and Gynecology \\ Faculty of Medicine Universitas Indonesia/ \\ Dr. Cipto Mangunkusumo Hospital \\ Jakarta
}

\begin{abstract}
Objective: To investigate the degree of cystocele and rectocele with a maximum of levator hiatal area (AHL) during Valsava.

Methods: Secondary data analysis of 90 patients with uterine prolapse January 2012 to November 2013 in the clinic Urogine-kologi RSCM, Jakarta. 3D/4D ultrasound measurement and pelvic organ prolapse system Quantification (POP-Q) stage I-IV cystocele and rectocele stage I-IV. All statistical analyses were analyzed using Stata 20 for Windows.

Results: Significant difference cystocele stage I-II $(n=25)$ with stage III-IV $(n=65)$, the maximum AHL with a difference of 4.33 $\mathrm{cm}^{2}(\mathrm{p}=0.040)$. In rectocele stage I-II $(\mathrm{n}=64)$ and stage III-IV (n $=26)$ of $3.85 \mathrm{~cm}^{2}(\mathrm{p}=0.130)$. AUC values for stage I-II and III-IV cystocele was 0.607 (IK95\% from 0.467 to 0.738 ), and the ROC for rectocele was 0.603 (IK95\% from 0.472 to 0.734 ). The ROC optimal cut point for cystocele stage I-II with III-IV with the highest sensitivity and specificity is $29 \mathrm{~cm}^{2}(0.523$ sensitivity, specificity $0.520)$, the rectocele is $30 \mathrm{~cm}^{2}(0.538$ sensitivity, specificity 0.584 )

Conclusion: There is a significant relationship between the degree of cystocele and area of the levator ani muscles when Valsava, but there is no relationship at rectocele. The value of maximum area under the curve (AUC) hiatal area of the levatorani muscle in distinguishing stage I-II and III-IV cystocele are relatively similar to rectocele stage I-II and III-IV. Optimal cut point hiatal area of the levatorani muscle in distinguishing stage I-II and III-IV cystocele is $29 \mathrm{~cm}^{2}$, while for rectocele is $30 \mathrm{~cm}^{2}$ with sensitivity and specificity values were quite good.
\end{abstract}

[Indones J Obstet Gynecol 2017; 5-4: 225-229]

Keywords: cystocele, levatorani hiatal area, pelvic organ prolapse, rectocele

\begin{abstract}
Abstrak
Tujuan: Mengetahui derajat sistokel dan rektokel dengan maksimal area hiatal levator (AHL) saat Valsava.

Metode: Analisa data sekunder 90 pasien prolaps uteri Januari 2012 hingga November 2013 di poliklinik Uroginekologi RSCM, Jakarta. Pengukuran ultrasonografi $3 D / 4 D$ dan pelvic organ prolapse quantification system (POP-Q) sistokel derajat I-IV dan rektokel derajat I-IV. Dianalisis dengan stata program 20 for windows.
\end{abstract}

Hasil: Perbedaan bermakna sistokel derajat I-II $(n=25)$ dengan derajat III-IV( $n=65)$, maksimal AHL dengan perbedaan sebesar 4,33 $\mathrm{cm}^{2}(p=0,040)$. Pada rektokel derajat I-II $(n=64)$ dan derajat III-IV $(n=26)$ sebesar $3,85 \mathrm{~cm}^{2}(p=0,130)$. Nilai AUC untuk sistokel derajat I-II dengan III-IV adalah 0,607 (IK95\% 0,467 - 0,738), untuk rektokel adalah 0,603 (IK95\% 0,472 - 0,734). Titik potong optimal ROC untuk sistokel derajat I-II dengan III-IV dengan sensitivitas dan spesifitas tertinggi adalah $29 \mathrm{~cm}^{2}$ (sensitivitas 0,523, spesifitas 0,520), pada rektokel adalah $30 \mathrm{~cm}^{2}$ (sensitivitas 0,538, spesifitas $0,584)$.

Kesimpulan: Terdapat hubungan bermakna antara derajat sistokel dengan area hiatal otot levator ani saat valsava, namun tidak terdapat hubungan pada rektokel. Nilai area under curve maksimal area hiatal otot levator ani dalam membedakan sistokel derajat I-II dan IIIIV relatif sama dengan rektokel derajat I-II dan III-IV. Titik potong optimal area hiatal otot levator ani dalam membedakan sistokel derajat I-II dan III-IV adalah $29 \mathrm{~cm}^{2}$, sedangkan untuk rektokel adalah $30 \mathrm{~cm}^{2}$ dengan nilai sensitivitas dan spesifitas yang cukup baik.

[Maj Obstet Ginekol Indones 2017; 5-4: 225-229]

Kata kunci: area hiatal levator ani, prolaps organ panggul, rektokel, sistokel

\section{INTRODUCTION}

Levator ani muscle plays an essential role in holding pelvic organs. Impairment to the structure of this muscle may result in pelvic organ prolapse, particularly in the middle and anterior compartment. ${ }^{1,2}$ Prolapse of the anterior vaginal wall may occur due to weakness of the connective tissue and pubocervical fascia, which subsequently may involve bladder, which is known as cystocele, while the posterior wall prolapse may involve lower rectum, which is named as rectocele. Measurement of the area of levator ani hiatus is essential for predicting the occurrence of pelvic organ prolapse for women in the future, so that the potential occurrence of pelvic organ prolapse can be prevented early. 3,4

A study at Dr. Cipto Mangukusumo Hospital, Jakarta, Indonesia, in 2014 found a significant 
association between the degree of uterine prolapse and the area levator ani hiatus. Further studies providing the data on the relationship degree cystocele and rectocele with levator hiatal area when the valsava maneuver. This study will also determine the maximum Area Under the Curve (AUC) selevator hiatal area when the valsava maneuver to distinguish degrees of cystocele and rectocele. So in this study will be known relationship between the degree cystocele and rectocele with the size of the levatorani hiatal area.

Pelvic organ prolapse (POP) is anatomically defined as downward decent of pelvic organs into or through the vagina, perineum or ana canal. POP occurs due to impairment of the structural support and the mounting of the uterus and vagina. ${ }^{5}$ Prolapse of the anterior vaginal wall caused by weakness of the pelvic advocates may lead to cystocele. Symptoms often found on the anterior vaginal wall prolapse are frequency, urgency, intermittent urinary flow, straining during urination, incomplete bladder emptying and urine flow is not smooth.6,7 Posterior vaginal wall prolapse is caused by rectovaginal septal defect. This is known as rectocele. Several symptoms found in the posterior vaginal wall prolapse is strong straining during defecation, incomplete defecation, constipation, as well as manual evacuation digitally by exerting pressure on the perineum or vagina. ${ }^{8}$

Damage to the levator ani muscles will cause avulsion or overdistention of the levator ani, while damage to the neuromuscular will decrease levator ani tone. This will subsequently lead to the widespread area of the levator ani hiatus which in turn will lead to uterine prolapse, cystocele and rectocele. ${ }^{9,10}$ Damage and weakness of endopelvic fascia and vaginal wall will directly lead to uterine prolapse, cystocele, and rectocele. Several things including spontaneous labor or assisted vaginal delivery, macrosomia, prolonged second stage, extensive perineal tears, menopause, obesity, increased intra-abdominal pressure. ${ }^{11}$

\section{METHODS}

This was a cross-sectional study. This study was conducted at the Department of Obstetrics and Gynecology of Dr. Cipto Mangunkusumo Hospital, Jakarta, Indonesia during the period of May to June 2016. The medical records of patients diagnosed with uterine prolapse who went to the Urogynecologic Clinic of Dr. Cipto Mangunkusumo Hospital between January 2012 and November 2013 were evaluated. All statistical analyses were analyzed using Statistics Data Analysis 20 (Stata 20).

\section{RESULTS AND DISCUSSION}

A total of 90 subjects were recruited in this study. There were significant differences for the age of the patients in both groups. Patients with stage I-II cystocele were younger compared to the those with stage III-IV cystocele $(54.64 \pm 13.35$ vs 59.71 +9.40 ). This is consistent with a previous study by Patel et $\mathrm{al}^{12}$ which suggested that age was the main risk factor for the occurrence of primary POP. However, older age at delivery has not showed a clear correlation with the incidence of the primary POP. Those with older age was also associated with menopausal condition seen in this study. The prevalence of cystocele occurs more frequently in

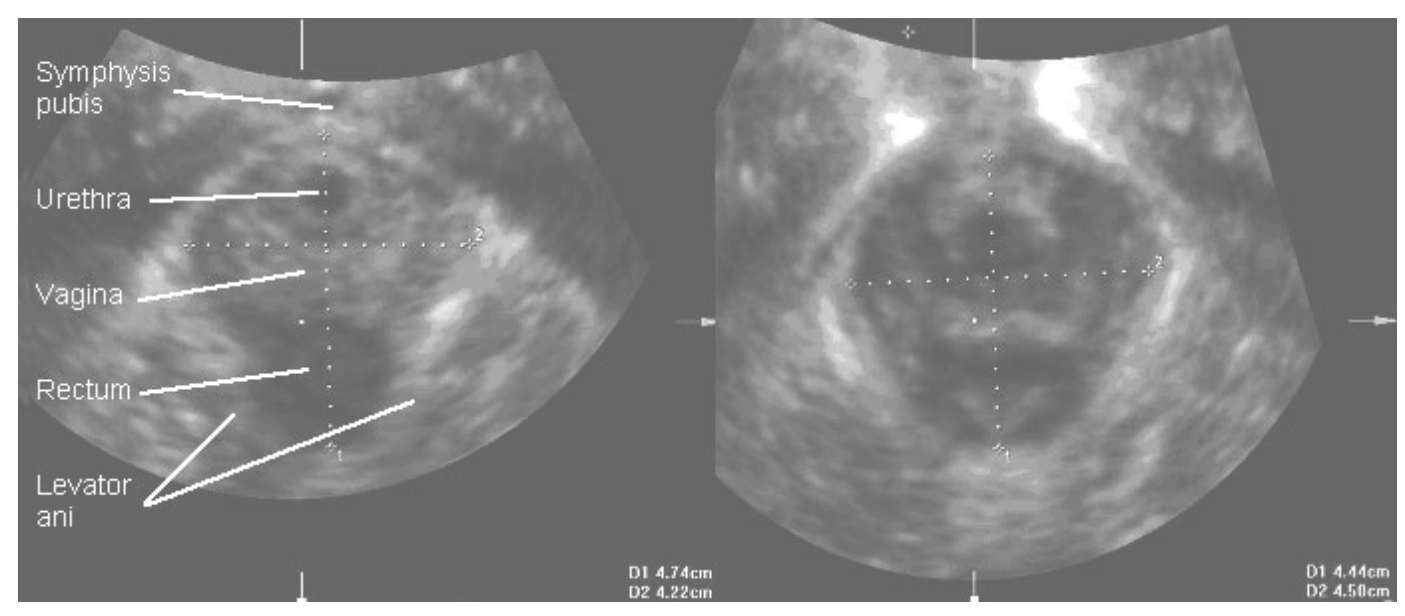

Figure 1. Levator hiatus during relaxation (left) and Valsalva maneuver (right) 
women who were in the postmenopausal state. Total parity was not associated with the incidence of POP in this study. This is contrast with a previous study conducted by Vergeldt et al. ${ }^{13}$ This difference may occur due to the distribution of the data subject of different studies, where the number of patients with a high degree of prolapse number were three times higher compared to the those with low degree prolapse. The baby's weight is also no effect on the incidence of cystocele and rectocele in the study sample. Vaginal delivery and parity was a risk factor that is often done research on the occurrence of cases of primary POP. ${ }^{14}$ The use of tools when parturition associated with a lower risk of developing high degree cystocele and rectocele III-IV in this study. These results are consistent with studies by Glazener which investigated the incidence of cystocele, rectocele and avulsion with the use of tools when parturition at 726 subjects. ${ }^{13}$

There was a significant difference between the maximum value of the area of levator ani hiatus during Valsava maneuver. The maximum value of the area of the levator ani hiatus on stage I-II cystocele was $28.45+7.82 \mathrm{~cm}^{2}$ lower than the hiatal area levatorani cystocele stage III-IV is 32.78 $+10.98 \mathrm{~cm}^{2}$. These results are consistent with previous studies by Vergeldt et all and Dietz. ${ }^{7}$ In those with rectocele, there were no found significant differences of the maximum value of the area of the levator ani hiatus. The results obtained in the different groups of rectocele with existing literature were due to the differences in sample size and distribution of the samples in this study. In this study, the results obtained were not statistically significant. ${ }^{13}$
The value of AUC obtained for groups of cystocele was 0.607 (CI 95\% from 0.467 to 0.738 ), which means the ability of discrimination in a category is, for groups rectocele obtained 0.603 (CI $95 \%$ from 0.472 to 0.734 ), which means the ability of discrimination in a category is, Results of statistical analysis, the best cut point to be limits in distinguishing low incidence and high degree cystocele is $29 \mathrm{~cm}^{2}$. For the cut-off point, the value of 0.523 was good enough. The sensitivity and specificity value is 0.520 , while for rectocele is 30 $\mathrm{cm}^{2}$, with a 0.538 value of sensitivity and specificity values 0.584 .

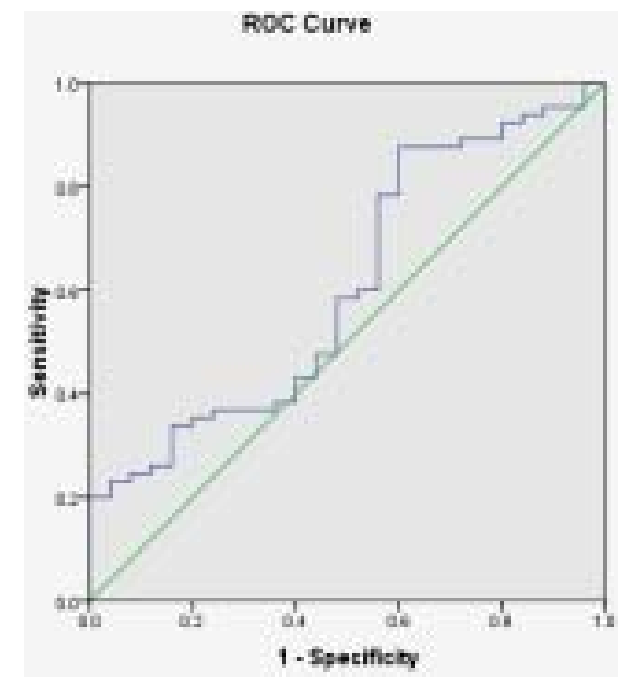

Figure 2. ROC curve mask AHL group cystocele stage I-II and III-IV

Table 1. Comparison of the Max Value of the AHL on Cystocele Group Stage I-II and III-IV

\begin{tabular}{lcccc}
\hline \hline Cystocele & N & $\begin{array}{c}\text { Average +SD } \\
\left(\mathbf{c m}^{2}\right)\end{array}$ & $\begin{array}{c}\text { Mean difference } \\
(\mathbf{C I} \text { 95\%) }\end{array}$ & $\mathbf{p}$ \\
\hline Stage I-II & 25 & $28.45+7.82$ & $4.33(-0.20-8.46)$ & 0.040 \\
Stage III-IV & 65 & $32.78+10.98$ & & \\
\hline \hline
\end{tabular}

Table 2. Comparison of the Max Value of the AHL in Group Rectocele Stage I-II and III-IV

\begin{tabular}{lcccc}
\hline \hline Cystocele & $\mathbf{N}$ & $\begin{array}{c}\text { Average }+ \text { SD } \\
\left(\mathbf{c m}^{\mathbf{2}}\right)\end{array}$ & $\begin{array}{c}\text { Mean difference } \\
\text { (CI 95\%) }\end{array}$ & $\mathbf{p}$ \\
\hline Stage I-II & 64 & $30.47+9.80$ & $3.85(-1.19-8.89)$ & 0.130 \\
Stage III-IV & 26 & $34.32+11.10$ & & \\
\hline \hline
\end{tabular}




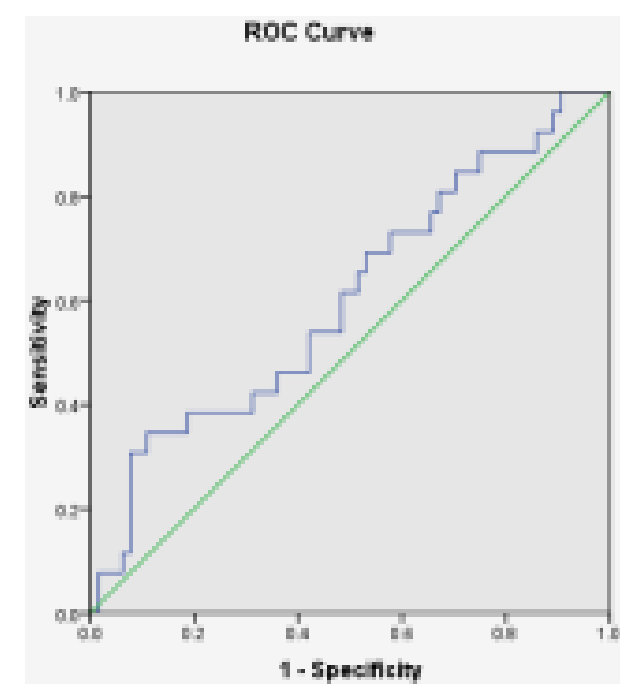

Figure 3. ROC curve max AHL rectocele group stage I-II and III-IV

Table 3. Assessment of Sensitivity and Specificity to Distinguish Max AHL Group Cystocele Stage I-II and III-IV at some Cut Point

\begin{tabular}{ccc}
\hline \hline Cut Point & Sensitivity & Specificity \\
\hline 24 & 0.800 & 0.400 \\
24.5 & 0.785 & 0.400 \\
25 & 0.785 & 0.440 \\
25.5 & 0.769 & 0.440 \\
26 & 0.708 & 0.440 \\
26.5 & 0.631 & 0.440 \\
27 & 0.600 & 0.440 \\
27.5 & 0.600 & 0.440 \\
28 & 0.585 & 0.480 \\
28.5 & 0.554 & 0.480 \\
29 & 0.523 & 0.520 \\
29.5 & 0.508 & 0.520 \\
30 & 0.477 & 0.520 \\
30.5 & 0.477 & 0.520 \\
\hline
\end{tabular}

Table 4. Assessment of Sensitivity and Specificity to Distinguish Max AHL group Rectocele Stage I-II and III-IV at some Cut Point.

\begin{tabular}{ccc}
\hline \hline Cut Point & Sensitivity & Specificity \\
\hline 23 & 0.877 & 0.380 \\
23.5 & 0.877 & 0.400 \\
24 & 0.815 & 0.400 \\
24.5 & 0.785 & 0.400 \\
25 & 0.785 & 0.440
\end{tabular}

\begin{tabular}{cll}
25.5 & 0.769 & 0.440 \\
26 & 0.692 & 0.440 \\
27 & 0.692 & 0.484 \\
27.5 & 0.692 & 0.484 \\
28 & 0.654 & 0.484 \\
28.5 & 0.615 & 0.512 \\
29 & 0.577 & 0.512 \\
29.5 & 0.538 & 0.512 \\
30 & 0.538 & 0.584 \\
30.5 & 0.500 & 0.584 \\
\hline \hline
\end{tabular}

\section{CONCLUSION}

The degree of cystocele is associated with area of the levator ani hiatus during Valsava maneuver. However, there is no association between the degree of rectocele and area of levator ani hiatus during Valsava. The value of AUC maximum area of the levator hiatus muscle in distinguishing stage I-II and III-IV cystocele are relatively similar to stage I-II and III-IV rectocele.

\section{REFERENCES}

1. Clark NA BC, Yousef A, DeLancey JOL. Levator defects effect perineal position independently of prolaps status. Am J Obstet Gynecol. 2010; 203(6): e17-e22.

2. Durnea CM KA, Kenny LC, Durnea UA, Smyth MM, O'Reilly BA. Prevalence, etiology and risk factors of pelvic organ prolapse in premenopausal primiparous women. Int Uro-gynecol J. 2014; 25: 1463-70.

3. Laila Najjari JH, Pia Larscheid, Thomas Papathemelis, and NicolaiMaass. Perineal Ultrasound as a Complement to POP$\mathrm{Q}$ in the Assessment of Cystoceles. Bio Med Research Int. 2014: 1-8.

4. Schettino MT DE, Rossi C, Panariello A, Vascone C, Coppola G, Iervolino SA, Assisi DD, Mainini G, Torella M. Possible role of perineal ultrasound in the diagnosis of cystocele. Clin Exp Obstet Gynecol. 2015; 42: 321-6.

5. Shek KL DH. The effect of childbirth on hiatal dimensions. Obstet Gynecol. 2009; 113: 1272-8.

6. Barber MD MC. Epidemiology and outcome assessment of pelvic organ prolapse. Int Urogynecol J. 2013; 24: 1783-90.

7. Dietz HP HK, Wong V. The natural history of cystocele recurrence. Int Urogynecol J. 2014; 25: 1053-7.

8. Collins SA1 OSD, Lasala CA. Correlation of POP-Q posterior compartment measures with defecatory dysfunction. Int Urogynecol J. 2012: 23.

9. Dietz HP FA, Shek KL, Kirby A. Avulsion injury and levator hiatal ballooning: two independent risk factors for prolapse? An observational study. Acta Obstet Gynecol Scand. 2012; 91: 211-4.

10. Abdool Z SK, Dietz HP. The effect of levator avulsion on hiatal dimension and function. Am J Obstet Gynecol. 2009, 201: 89e1-5. 
11. de Landsheere L BS, Munaut C, Nusgens B, Rubod C, Noel A, Foidart JM, Cosson M, Nisolle M. Changes in elastin density in different locations of the vaginal wall in women with pelvic organ prolapse. Int Urogynecol J. 2014; 25: 1673-81.

12. Patel DA, Xu X, Thomason AD, Ransom SB, Ivy JS, Delancet JO. Childbirth and pelvic flooe dysfunction: an epidemiologic approach to the assessment of prevention opportunities at delivery. Am J Obstet Gynecol. 2006; 195: 23-8.
13. Vergeldt TFM, Weemhoff M, IntHout J, Kluivers KB. Risk factors for pelvic organ prolapse and its recurrence: a systematic review. Int Urogynecol J. 2015; 26(11): 1559-73.

14. Glazener C, Elders A, Macarthur C, Lancashire RJ, Herbison P, Hagen S, Dean N, Bain C, Toozs-Hobson P, Richardson K, McDonald A, McPherson G, Wilson D. Childbirth and prolapse: long-term associations with the symptoms and objective measurement of pelvic organ prolapse. BJOG. 2013; 120(2): 161-8. doi: 10.1111/1471-0528.12075. 